\title{
Human immunodeficiency virus and human papilloma virus - why HPV-induced lesions do not spontaneously resolve and why therapeutic vaccination can be successful Sjoerd H van der Burg*1,2 and Joel M Palefsky ${ }^{1,2}$
}

Address: ${ }^{1}$ Department of Clinical Oncology, Leiden University Medical Center, Leiden, The Netherlands and ${ }^{2}$ Department of Medicine, University of California, San Francisco, San Francisco, CA, USA

Email: Sjoerd H van der Burg* - shvdburg@lumc.nl; Joel M Palefsky - palefskyj@gcrc.ucsf.edu

* Corresponding author

Published: 18 December 2009

Journal of Translational Medicine 2009, 7:108

doi:10.1186/1479-5876-7-108

Received: 5 November 2009

Accepted: 18 December 2009

This article is available from: http://www.translational-medicine.com/content/7/I//08

(c) 2009 Burg and Palefsky; licensee BioMed Central Ltd.

This is an Open Access article distributed under the terms of the Creative Commons Attribution License (http://creativecommons.org/licenses/by/2.0), which permits unrestricted use, distribution, and reproduction in any medium, provided the original work is properly cited.

\begin{abstract}
HIV and HPV can both cause chronic infections and are acquired during sexual contact. HIV infection results in a progressive loss of $C D 4+T$ cells that is associated with an increased prevalence of HPV infections, type-specific persistence and an increase in HPV-associated malignancies. On the one hand this illustrates the important role of HPV-specific CD4+ helper Tcell immunity, on the other it shows the Achilles heel of the HPV-specific immune response. The use of highly active antiretroviral therapy (HAART) results in a rapid reduction of HIV and a reconstitution of systemic CD4+ T-cell levels. The use of HAART thus has the potential to raise immunity to HPV but to the surprise of many, the incidence of HPV-induced diseases has increased rather than declined since the introduction of HAART. Here, the knowledge on how HPV-induced diseases develop in the face of a non-compromised immune system will be used to explain why the effect of HAART on HPV-induced diseases is modest at best. Furthermore, exciting new data in the field of therapeutic vaccines against HPV will be discussed as this may form a more durable and clinically successful therapeutic approach for the treatment of HPV-induced high-grade lesions in HIV-positive subjects on HAART.
\end{abstract}

\section{Introduction}

Human papilloma virus (HPV) is the most commonly sexually transmitted agent worldwide. A high prevalence of HPV has been reported especially among young sexually active individuals. Persistent infection with oncogenic HPV types, in particular HPV16, are causally related to the development of anogenital lesions like cervical intra-epithelial neoplasia (CIN), vulvar intraepithelial neoplasia (VIN) and anal intraepithelial neoplasia (AIN) as well as their subsequent progression to invasive squamous cell carcinoma [1-5]. While HPV infection is asymptomatic in the great majority of immunocompetent individuals, a small proportion of men and women fail to control viral infection and develop HPV-related malignancies.

The incidence of cervical as well as anal precursor lesions and cancer is markedly higher in HIV-positive men and women [6-8] compared with HIV-negative men and women. In men who have sex with men (MSM) the incidence of AIN and anal cancer was already particularly high and incidence rates are substantially elevated in the population of HIV-positive MSM. Furthermore, the risk of 
other HPV-associated cancers of the oropharynx, penis, vagina, and vulva is also increased among persons with AIDS [9]. The introduction of antiretroviral therapy in the mid-nineties restored immune responses to several AIDSdefining opportunistic infectious agents such as cytomegalovirus and human herpes virus- 8 , as well as significantly changed the prognosis and mortality rates of HIV-infected subjects. However, the longer survival of highly active antiretroviral therapy (HAART)-treated subjects led to a high incidence and steady increase in HPV-related malignancies both in women and men [7-11]. This counterintuitive observation of detecting more HPV-induced malignancies after restoration of the immune system requires an explanation, and the answer may be found in studies on HPV-specific immunity in immune competent individuals.

\section{CD4+ T cells, the Achilles heel of HPV-specific immunity}

Epidemiological studies have shown a strikingly high prevalence of oncogenic HPV types in the general population [12-15]. For example the cumulative lifetime incidence of HPV16 infection is estimated to be over 50\% [16]. In most healthy persons the immune system succeeds in eliminating oncogenic HPV types before malignancies develop [13,17]. Natural history studies [18] show that most $(90 \%)$ low-grade cervical intraepithelial neoplasia (CIN 1) can regress spontaneously and this is attributed to the fact that many CIN 1 lesions are induced by the low-risk non-oncogenic HPV types as well as the development of HPV antigen-specific cellular immune responses. At the time of spontaneous regression of HPVinfected genital warts, the lesions are infiltrated with CD8+ cytotoxic T-cells (CTL), CD4+ T-cells and macrophages [19]. This observation fits well with the general notion that the protective immune response to chronic viral infections is a polyfunctional type 1 response of both CD4+ helper T cells and CD8+ cytotoxic T cells [20-24]. In addition to their direct effects, virus-specific CD4+ T cells are needed to sustain CD8+ effector T-cell responses as well as to activate innate effector cells. Comprehensive studies on HPV16-specific immunity have revealed that HPV16-specific CD4+ T-cell responses and HPV16-specific CTL responses directed against the viral early antigens E2, E6 and/or E7 are detected in peripheral blood mononuclear cell (PBMC) cultures of the majority of healthy individuals. In general, HPV-specific CD4+ T-cell immunity comprises both Th1- (IFN $\gamma$ ) and Th2-producing (IL5) T cells reactive to a broad array of epitopes within these antigens [25-30]. Moreover, these circulating HPV16-specific CD4+ and CD8+ T cells are able to migrate from the circulation to the epithelium upon antigenic challenge in healthy subjects [31]. These observations suggest that successful defense against HPV16 infection is commonly associated with the induction of a systemic effector T-cell response against the viral early antigens. This notion is sustained by our recent observation that the vaccineinduced regression of HPV16-induced high-grade VIN was associated with a strong and broad IFN $\gamma$-associated CD4+ T-cell response against E6 and E7 [32].

Unfortunately, HIV infection results in a progressive loss of CD4+ T cells. When one considers the type of immune response needed to deal with chronic viral infections in general, the frequent detection of HPV-specific CD4+ Tcell reactivity in protected healthy individuals as well as the association between HPV-specific CD4+ T cells and regression of HPV-induced premalignant lesions, it becomes clear why the loss of CD4+ T-cells is associated with an increased prevalence of HPV infections, type-specific persistence and an increase of HPV-associated malignancies [33]. On the one hand this illustrates the important role of HPV-specific CD4+ helper T-cell immunity, on the other it shows that HPV-specific CD4+ T-cell immunity is the Achilles heel of protection against HPVinduced disease.

\section{Restoration of CD4+ T-cell immunity to pathogens requires antigen exposure under inflammatory conditions}

HAART consists of an antiretroviral drug regimen which combines inhibitors of the HIV reverse transcriptase and protease. Depending on the HIV disease stage and the level of HIV viral control over time, the use of HAART results in an increase in the number of CD4+ T cells that may reach (near) normal counts within 2-6 years [34]. Initially HAART induces a rapid increase in CD4+ T-cell counts as a result of the redistribution of memory $\mathrm{T}$ cells that had been sequestered in inflamed lymphoid tissues that have come to rest as a result of a significant drop of the HIV viral load when HIV is controlled. The second phase is slower and thought to reflect the re-expansion of naïve CD4+ T cells and re-diversification of the T-cell repertoire following the treatment of this chronic infection [34].

The increase in CD4+ T-cell counts coincides with the decrease in several of the AIDS-defining illnesses arising from opportunistic infections and the detection of T-cell responses against agents such as CMV [35], Candida, Mycobacterium and Streptococcus $[36,37]$. This occurs a few months after therapy has commenced and is thought to arise after exposure to sufficient quantities of the targeted antigens upon (re-)infection with these pathogens. HIV-specific T cells are only detected at the time of a primary infection or when HAART is given before the onset of CD4+ T cell depletion [34] but not in chronicallyinfected HAART-treated patients $[36,37]$. However, Jansen et al. observed an increase in HIV-specific CD4+ T-cell proliferative capacity after 55 months of HAART [38]. 
These data indicate that chronic infection results in the depletion of HIV-specific immunity - which sounds reasonable as CD4+ T cells are a prime target of HIV - and suggest that new thymic emigrants are only stimulated to respond to HIV over time. The difference in the kinetics of the cellular response to opportunistic pathogens and HIV is best explained by a difference in the host's exposure to antigenic stimuli. The rapid decline of HIV - and as such the amount of HIV antigens which can be presented to the immune system - following HAART is likely to result in suboptimal stimulation of the immune system to HIV. This notion is sustained by the observations that HIV-specific central and effector CD4+ and CD8+ memory T cell populations rapidly disappear from the peripheral blood of infected individuals under HAART [39] while re-exposure of the immune system to HIV during structured therapy interruption (STI) after one year of HAART results in expansion of HIV-specific CD4+ and CD8+ T cells [40]. The important point here is that restoration of immunity in HIV-infected patients on HAART to infectious agents requires (re-)infection and exposure to sufficient amounts of pathogen-derived antigens under inflammatory conditions.

\section{Failure to restore protective HPV-specific immunity in HIV-positive patients on HAART}

Thus far, there is no evidence showing that the oncogenic behaviour of HPV is altered by HIV[41] and while HIVinduced immunosuppression can be held accountable for the increased incidence of precursor lesions it does not explain why these lesions do not resolve when HAART is given and immunosuppression is alleviated.

Some previous studies do report a positive effect of HAART on the natural history of HPV-induced pre-malignancies in HIV-infected subjects. A close look at the data shows us that most of the effects noted are among patients with low-grade lesions with response rates of $35 \%$ $[42,43]$, which is still lower than what is observed in immunocompetent individuals of whom $\sim 60 \%$ clears a low-grade CIN within 12 months [44]. Notably, 25\% of the HIV-infected low-grade CIN subjects on HAART still progress to high-grade CIN [43] and HIV-infected patients with high-grade CIN often do not show regression when treated with HAART $[43,45]$. One should realize that in many HIV-positive patients on HAART the HPV infections and HPV-induced lesions are not newly acquired but reflect persistence and/or recently reactivated prior infections of the HPV types detected despite an increase in CD4+ T cell levels [8]. In a number of cases it may also reflect new exposure [46]. The persistence of HPV and HPV-induced lesions indicate that HPV-infection was not counteracted in the first place and that the virus was allowed to establish LSIL and/or HSIL lesions before the capacity of the immune system to respond was restored.
So what happens with the HPV-specific immune response in patients on HAART? It is hard to know as there are few studies on the kinetics of HPV-specific immunity during HAART. Fortunately, there is considerable knowledge on HPV-specific immunity in immunocompetent individuals that allows us to understand why HAART cannot simply restore full protective immunity to HPV in HIVinfected subjects.

\section{Immunity to HPV-induced lesions in immunocompetent individuals}

In contrast to the opportunistic pathogens or HIV, HPV is rather a stealthy virus as it causes minimal inflammation, allowing it to persist at detectable levels for 12-18 months in immunocompetent subjects [47]. From a teleologic point of view this is necessary for HPV as it requires the full cycle of keratinocyte differentiation to produce its own viral particles and inflammatory signals may jeopardize its capacity to replicate. Although much work is still needed in this area, HPV seems to alter transcriptional activity of the IFN $\beta$ and NFkB-pathways resulting in a decreased ability of keratinocytes to produce the necessary cytokines and chemokines to attract the adaptive immune system [48-50]. The identification of HPV-induced lowgrade or high-grade lesions reflects molecular changes in the normal program of epithelial cell differentiation that occur following infection. Importantly, the timely expression of viral gene products and the linked production of viral particles are progressively disturbed during neoplastic progression [51]. In addition, the development of such lesions is associated with a locally altered cytokine environment with an increase in IL-10 and a decrease in proinflammatory cytokines [52-54]. The progression rate of high-grade lesions of the cervix, vulva or anal region to cancer in immunocompetent subjects is similar among the different types of lesions (9-13\%) [55-57], and regressions are only occasionally observed.

A comparison of immune presentation of opportunistic pathogens and HPV indicates that there is less inflammation and there are lower amounts of antigens available to the immune system with HPV infection. One could compare the presentation of HPV antigens in immunocompetent subjects to that of HIV antigens in patients on HAART, as in both cases the induction of detectable immune responses may take a while. When HPV-induced lesions develop, the production of viral antigens is severely altered due to the loss of a productive infection. Some viral antigens are not produced anymore (e.g. E2) whereas others may increase in time (e.g. E7). Most importantly antigen-presenting cells (APC) that are present in the local region and whose normal role is to ingest and present the viral antigens to $\mathrm{T}$ cells, are functionally altered as these APC are exposed to an immunosuppressive environment and become tolerized [58]. As a 
consequence the immune response to HPV is different in patients with HPV-induced lesions when compared with healthy individuals who do not have HPV-associated disease (see above).

In a large prospective study on the clinical course of lowgrade CIN we have studied HPV16-specific immunity in relation to clinical outcome [59]. HPV16-specific IFN $\gamma$ associated T-cell responses were detected in only half of the patients with an HPV16+ low-grade CIN, and responses were predominantly to HPV16 E2 and E6. Interestingly, the presence of HPV16 E2-specific T-cell responses correlated with absence of progression of HPV16+ lesions but this was only a small group [59]. Thus the immune system clearly fails to activate CD4+ IFN $\gamma$-producing HPV-specific T cells in half of the immunocompetent patients with low-grade CIN and only in a minority of the subjects the immune response is strong enough to induce regression.

The HPV-specific immune response in patients with highgrade CIN lesions is even worse. The accumulated data from a number of different studies on patients with HPV16+ high-grade CIN revealed that HPV16-specific Tcell responses were absent in the circulation of the majority of patients who visit the clinic for treatment of an HPV16+ high-grade lesion. Notably, the quality of the immune response in those patients who did show HPV16-specific reactivity was low in the sense that most of the detected HPV16-specific T-cell responses did not include secretion of pro-inflammatory cytokines such as IFN $\gamma$. In the end, more than $75 \%$ of all patients with a high-grade lesion failed to develop an HPV16-specific cellular immune response which would remotely resemble that of what was seen in healthy individuals [26,59-62]. Importantly, HPV16-specific T-cell reactivity was predominantly found in patients returning to the clinic for repetitive treatment of a persistent or recurrent HPV16+ highgrade CIN after initial destructive treatment [61]. This suggests that the induction of HPV-specific reactivity in patients with high-grade CIN requires sufficient exposure to antigen (achieved by persistence/recurrence) as well as inflammation such as is caused by destructive treatment. Unfortunately, this is the case in only a minority of women with high-grade CIN. Moreover, when the viral antigens are presented it is usually in a suppressive environment and as a result a non-beneficial HPV-specific immune response develops that is unable to induce the regression of an HPV-induced lesion. This notion is consistent with our observation that high-grade CIN-infiltrating T-cell cultures can contain HPV16-specific regulatory T-cells [61]. Thus if an HPV-specific immune is present in patients with high-grade CIN it consists of T-cells that do not produce IFN $\gamma$ and sometimes even has a suppressive signature. This type of immunity is in clear contrast with that found in healthy individuals or patients in whom their lesions regressed [25-27,32,63]. Aforementioned data on HPV16-specific T-cell immunity in HIV-positive patients on HAART are lacking but it would be safe to assume that the response rate and type of HPV-specific immune response in HIV-positive patients on HAART at least is not better than that of immunocompetent patients with low-grade or high-grade lesions.

Current literature indicates that HPV-induced lesions are less likely to regress in immunocompetent [64] or HIVpositive patients [65] when these lesions - being either low-grade or high-grade - are induced by high-risk HPV types as compared to low-risk HPV types. Moreover, the accumulated data on HPV16-specific immunity in immunocompetent patients clearly show that - even when the immune system is not compromised - an established high-risk HPV-induced lesion fails to trigger a functional HPV-specific immune response. Considering that the prevalence of HPV and HPV-associated disease are much higher in HIV-infected men and women [8,66-69], it is highly likely that the HPV-specific immune response in patients on HAART will not be induced in most of them or in some cases may resemble that of non-immunocompromised patients with lesions, i.e., does not confer protective immunity.

It is not fair to expect that HAART would lead to regression of HPV-induced cancer as this also poses a general problem among immunocompetent patients with cancer. Furthermore, cervical cancer is strongly associated with failure to mount a strong HPV-specific type 1 T-helper and cytotoxic T lymphocyte (CTL) response and the induction of HPV-specific regulatory T cells [26,30,70-72]. Furthermore, CD8+ T cells may fail to migrate into the tumor cell nests and when tumors are infiltrated by CD8 T cells it coincides with infiltration by $\mathrm{CD} 4+$ Foxp3+ regulatory $\mathrm{T}$ cells. Moreover, half of the tumor-infiltrating $\mathrm{T}$ cells express the programmed cell death receptor 1 as a sign of T-cell exhaustion [73-75]. In addition, the loss of human leukocyte antigens - which presents antigens to the T cells - is often observed and has a clear negative impact on patient survival [74].

\section{Non-specific treatment is associated with high recurrence rates}

Screening and treatment options for CIN and cancer are well established and consequently the incidence of cervical cancer in HIV-positive women has not increased following the implementation of HAART. There is, however, a strong increase in the incidence of anal diseases in both men and women [10]. Although cytological screening for AIN - analogous to cervical screening - has been proposed [76] this is not common practice. Similarly, treatment guidelines for anal lesions are yet not available but the dif- 
ferent strategies used so far fall into the categories of topical treatments, ablative treatments and immunotherapy. In this they resemble current treatment options used for the treatment of VIN in immunocompetent patients.

In a recent review of Kreuter et al. [77] an overview on the response rates and recurrence rates associated with different therapies for AIN is presented. In summary, ablative treatments (e.g. surgery, infrared, laser therapy) in general show a high response rate to treatment but also a high recurrence rate (38-79\%) within an average of 1-2 years. A few studies indicated that topical treatment of patients with AIN1-AIN3 with imiquimod may result in good clinical responses in patients with good compliance [78-80], albeit that these results have to be confirmed by others. Notably, despite good initial results the recurrence rate of $26-29 \%$ is still high [78-80]. If the response of AIN to imiquimod is indeed that good, it resembles that seen for the treatment of vulvar lesions in immunocompetent patients [81] in whom clinical response was related to the presence of weak IFN $\gamma$-producing HPV-specific T cells [63]. In view of this association between HPV-immunity and therapy response one may expect that also the responsiveness of HIV-positive AIN patients on HAART to imiquimod is related to the presence of HPV-specific immune responses. This suggests that HPV-specific immunity may also develop in patients with AIN on HAART albeit not sufficiently to induce the regression of the lesion without the help of a local induced of inflammation such as imiquimod. To clarify this issue new studies are needed to measure HPV-specific immunity in HAART-treated patients.

\section{HPV-specific therapeutic vaccination to treat may now become an option}

The clear link between HPV16 and cancers of the cervix, vulva and anal region has prompted the development of two types of vaccines. One type is focused on the prevention of high-risk HPV-infection for which Franceschi and De Vuyst argued that its success to prevent AIN and anal cancer depends on the administration of the vaccine before onset of sexual activity, its protective efficacy in men as well as the willingness to expand vaccine programs to both sexes [82]. The other type is a therapeutic vaccine aiming at strengthening the HPV16-specific T-cell response. In contrast to the natural context in which the immune system is exposed to lesion-derived HPV antigens, therapeutic vaccines can ensure the deliverance of sufficient quantities of HPV antigens in a highly stimulatory context, and as such may be able to restore an adequate HPV-specific immune response able to induce the regression and clearance of HPV-induced lesions. Thus far, two vaccines have been used to treat high-grade AIN in HIV-negative men (ZYC101) or HIV-positive men (SGN-00101). The vaccines were well-tolerated but did not induce clinical responses higher than what would spontaneously occur in these patient populations $[83,84]$. This result was not specific to AIN, since these vaccines also were unable to induce regression of CIN in immunocompetent patients[85,86].

Recently, a different type of vaccine consisting of overlapping HPV16 E6 and E7 synthetic long peptides (HPV16SLP), was reported to induce strong and broad CD4+ Thelper and CD8+ CTL responses in $>95 \%$ of patients with HPV16-induced cervical cancer $[87,88]$. The reason for its strong immunogenicity has been extensively reviewed [89]. A phase II clinical trial in which patients with VIN3 were treated with HPV16-SLP showed an objective clinical response rate of $79 \%$ and complete and durable ( $>24$ months) complete regression of the lesion in $47 \%$ of the patients [32]. The spontaneous regression of these lesions is $<1.5 \%$ [90]. Furthermore, there was a clear correlation with the strength of the IFN $\gamma$-producing HPV16-specific Tcell response and clinical outcome [32]. Interestingly, about half of the patients treated as well as half of the patients with a complete regression had multifocal disease some of which extended to the perianal region. Because of the similarities between immunocompetent patients and HIV-positive patients on HAART, in particular their restored immune response to opportunistic infections, these results offer hope for the treatment of HIV-positive patients on HAART. There are, however, still many issues to consider as we don't fully understand HPV-specific immunity in HIV-positive patients on HAART yet. One of these issues is the size of the lesion as in many cases HIVpositive patients have large lesions. The relatively larger VIN3 lesions were less likely to regress in immunocompetent VIN3 patients with HPV16-SLP [32] and this is clearly associated with an altered immune response (van der Burg, unpublished), suggesting that if one would like to have a chance to be successful one should start treatment as soon as patients receive HAART and/or while lesions are limited in size. One could even imagine vaccinating patients showing only the signs of an HPV16 infection with HPV16-SLP if significant reduction in development of HPV16-related disease can be demonstrated in prospective studies.

\section{Abbreviations}

AIN: anal intraepithelial neoplasia; APC: antigen presenting cell; CIN: cervical intra-epithelial neoplasia; CTL: cytotoxic T lymphocyte; HAART: highly active antiretroviral therapy; HIV: Human Immunodeficiency Virus; HPV: Human Papilloma Virus; IFN: interferon; SLP: synthetic long peptides; VIN: vulvar intraepithelial neoplasia.

\section{Competing interests}

SHvdB in an employee of the Leiden University Medical Center (LUMC), which holds a patent on the use of syn- 
thetic long peptides as vaccine (US 7,202,034: Long peptides of 22-45 amino acid residues that induce and/or enhance antigen specific immune responses). $\mathrm{SHvdB}$ is one of the inventors of the patent and reports to serve as a non-paid member of the strategy team and steering committee of ISA Pharmaceuticals, a biotech company which has licensed the patent from the LUMC. SHvdB has not received any payment for speaking, consulting, patents or royalties with respect to the present study.

JMP has not received any payment for speaking, consulting, patents or royalties with respect to the present study.

\section{Authors' contributions}

SHvdB and JMP drafted, read and approved the final manuscript.

\section{Acknowledgements}

Dr. Van der Burg is financially supported by several grants from the Dutch Cancer Society (including RUL 2007-3848) and from ZonMW of the Netherlands Organisation for Scientific Research (including NWO 917.56.3II). Dr. Palefsky is supported by a grant from the American Caner Society and National Institutes of Health grants U0ICA700I 9 and U0ICA070047.

\section{References}

I. Walboomers JM, Jacobs MV, Manos MM, Bosch FX, Kummer JA, Shah KV, Snijders PJ, Peto J, Meijer CJ, Munoz N: Human papillomavirus is a necessary cause of invasive cervical cancer worldwide. J Pathol 1999, 189:12-19.

2. Weaver BA: Epidemiology and natural history of genital human papillomavirus infection. J Am Osteopath Assoc 2006, 106:S2-8.

3. Wheeler CM: Natural history of human papillomavirus infections, cytologic and histologic abnormalities, and cancer. Obstet Gynecol Clin North Am 2008, 35:519-536. vii

4. Bosch FX, Burchell AN, Schiffman M, Giuliano AR, de Sanjose S, Bruni L, Tortolero-Luna G, Kjaer SK, Munoz N: Epidemiology and natural history of human papillomavirus infections and typespecific implications in cervical neoplasia. Vaccine 2008, 26(Suppl 10):KI-16.

5. Bosch FX, Lorincz A, Munoz N, Meijer CJ, Shah KV: The causal relation between human papillomavirus and cervical cancer. J Clin Pathol 2002, 55:244-265.

6. Frisch M, Biggar RJ, Engels EA, Goedert J]: Association of cancer with AIDS-related immunosuppression in adults. Jama 2001 , 285: |736- 1745 .

7. Hoots BE, Palefsky JM, Pimenta JM, Smith JS: Human papillomavirus type distribution in anal cancer and anal intraepithelial lesions. Int J Cancer 2009, I 24:2375-2383.

8. Palefsky JM: Cervical human papillomavirus infection and cervical intraepithelial neoplasia in women positive for human immunodeficiency virus in the era of highly active antiretroviral therapy. Curr Opin Oncol 2003, I 5:382-388.

9. Chaturvedi AK, Madeleine MM, Biggar RJ, Engels EA: Risk of human papillomavirus-associated cancers among persons with AIDS. J Natl Cancer Inst 2009, I 0 I: I I 20- I I 30.

10. Palefsky J: Human papillomavirus-related disease in people with HIV. Curr Opin HIV AIDS 2009, 4:52-56.

II. Kreuter A, Wieland U: Human papillomavirus-associated diseases in HIV-infected men who have sex with men. Curr Opin Infect Dis 2009, 22:109-II4.

12. Ho GY, Bierman R, Beardsley L, Chang CJ, Burk RD: Natural history of cervicovaginal papillomavirus infection in young women. N Engl J Med 1998, 338:423-428.

13. Koutsky L: Epidemiology of genital human papillomavirus infection. Am J Med 1997, 102:3-8.

14. Nielson CM, Harris RB, Dunne EF, Abrahamsen M, Papenfuss MR, Flores R, Markowitz LE, Giuliano AR: Risk factors for anogenital human papillomavirus infection in men. I Infect Dis 2007, 196: I |37-I|45

15. Nyitray A: Anal cancer and human papillomaviruses in heterosexual men. Curr Oncol 2008, I 5:204-205.

16. Helmerhorst TJ, Meijer CJ: Cervical cancer should be considered as a rare complication of oncogenic HPV infection rather than a STD. Int J Gynecol Cancer 2002, I 2:235-236.

17. Evander M, Edlund K, Gustafsson A, Jonsson M, Karlsson R, Rylander $E$, Wadell G: Human papillomavirus infection is transient in young women: a population-based cohort study. J Infect Dis 1995, I7 1:1026-1030.

18. Moscicki AB, Schiffman M, Kjaer S, Villa LL: Chapter 5: Updating the natural history of HPV and anogenital cancer. Vaccine 2006, 24(Suppl 3):42-5I.

19. Coleman N, Birley HD, Renton AM, Hanna NF, Ryait BK, Byrne M, Taylor-Robinson D, Stanley MA: Immunological events in regressing genital warts. Am J Clin Pathol 1994, I 02:768-774.

20. Zajac AJ, Murali-Krishna K, Blattman JN, Ahmed R: Therapeutic vaccination against chronic viral infection: the importance of cooperation between CD4+ and CD8+ T cells. Curr Opin Immunol 1998, 1 0:444-449.

21. Harari A, Dutoit V, Cellerai C, Bart PA, Du Pasquier RA, Pantaleo G: Functional signatures of protective antiviral $\mathrm{T}$-cell immunity in human virus infections. Immunol Rev 2006, 2 I I:236-254.

22. Matloubian M, Concepcion RJ, Ahmed R: CD4+ T cells are required to sustain CD8+ cytotoxic $T$-cell responses during chronic viral infection. J Virol 1994, 68:8056-8063.

23. Cardin RD, Brooks JW, Sarawar SR, Doherty PC: Progressive loss of CD8+ $T$ cell-mediated control of a g-Herpesvirus in the absence of CD4+T cells. J Exp Med 1996, I 84:863-87I.

24. Walter EA, Greenberg PD, Gilbert MJ, Finch RJ, Watanabe KS, Thomas ED, Riddell SR: Reconstitution of cellular immunity against cytomegalovirus in recipients of allogeneic bone marrow by transfer of T-cell clones from the donor. N Engl J Med 1995, 333:1038-1044.

25. de Jong A, Burg SH van der, Kwappenberg KM, Hulst JM van der, Franken KL, Geluk A, van Meijgaarden KE, Drijfhout JW, Kenter G, Vermeij P, Melief CJM, Offringa R: Frequent detection of human papillomavirus 16 E2-specific T-helper immunity in healthy subjects. Cancer Res 2002, 62:472-479.

26. de Jong A, van Poelgeest MI, Hulst JM van der, Drijfhout JW, Fleuren G], Melief C], Kenter G, Offringa R, Burg SH van der: Human papillomavirus type I6-positive cervical cancer is associated with impaired CD4+ T-cell immunity against early antigens E2 and E6. Cancer Res 2004, 64:5449-5455.

27. Welters MJ, de Jong A, Eeden SJ van den, Hulst JM van der, Kwappenberg KM, Hassane S, Franken KL, Drijfhout JW, Fleuren GJ, Kenter G, Melief CJM, Offringa R, Burg SH Van der: Frequent display of human papillomavirus type 16 E6-specific memory t-Helper cells in the healthy population as witness of previous viral encounter. Cancer Res 2003, 63:636-64I.

28. Nakagawa M, Stites DP, Farhat S, Sisler JR, Moss B, Kong F, Moscicki A, Palefsky JM: Cytotoxic T lymphocyte responses to E6 and E7 proteins of human papillomavirus type 16: relationship to cervical intraepithelial neoplasia. JlnfectDis 1997, I75:927-931.

29. Nakagawa M, Stites DP, Patel S, Farhat S, Scott M, Hills NK, Palefsky $J M$, Moscicki $A B$ : Persistence of human papillomavirus type 16 infection is associated with lack of cytotoxic $T$ lymphocyte response to the E6 antigens. J Infect Dis 2000, I 82:595-598.

30. Bontkes HJ, de Gruijl TD, Muysenberg AJ van den, Verheijen RH, Stukart MJ, Meijer CJ, Scheper RJ, Stacey SN, Duggan-Keen MF, Stern PL, Man S, Borysiewicz LK, Walboomers JM: Human papillomavirus type 16 E6/E7-specific cytotoxic $T$ lymphocytes in women with cervical neoplasia. Int J Cancer 2000, 88:92-98.

31. Hende $M$ van den, van Poelgeest MI, Hulst JM van der, de Jong J, Drijfhout JW, Fleuren GJ, Valentijn AR, Wafelman AR, Slappendel GM, Melief C], Offringa R, burg SH Van der, Kenter GG: Skin reactions to human papillomavirus (HPV) 16 specific antigens intradermally injected in healthy subjects and patients with cervical neoplasia. Int J Cancer 2008, I 23: |46-| 52.

32. Kenter G, Welters MJ, Valentijn AR, Lowik MJ, Berends-van der Meer DM, Vloon AP, Essahsah F, Fathers LM, Offringa R, Drijfhout JW, Wafelman AR, Oostendorp J, Fleuren GJ, Burg SH Van der, Melief CJM: Effective treatment of vulvar intraepithelial neoplasia by vaccination against the oncopoteins E6 and E7 of human 
papillomavirus type 16. New England Journal of Medicine 2009, 36 I: $1838-1847$.

33. Ahdieh L, Klein RS, Burk R, Cu-Uvin S, Schuman P, Duerr A, Safaeian $M$, Astemborski J, Daniel R, Shah K: Prevalence, incidence, and type-specific persistence of human papillomavirus in human immunodeficiency virus (HIV)-positive and HIV-negative women. J Infect Dis 200I, 184:682-690.

34. Carcelain G, Debre P, Autran B: Reconstitution of CD4+ T lymphocytes in HIV-infected individuals following antiretroviral therapy. Curr Opin Immunol 200I, 13:483-488.

35. Li TS, Tubiana R, Fillet AM, Autran B, Katlama C: Negative result of cytomegalovirus blood culture with restoration of CD4+ T-cell reactivity to cytomegalovirus after HAART in an HIVI-infected patient. J Acquir Immune Defic Syndr Hum Retrovirol I 999, 20:5I4-5I5

36. Rinaldo CR Jr, Liebmann JM, Huang XL, Fan Z, Al-Shboul Q, McMahon DK, Day RD, Riddler SA, Mellors JW: Prolonged suppression of human immunodeficiency virus type I (HIV-I) viremia in persons with advanced disease results in enhancement of CD4 T cell reactivity to microbial antigens but not to HIV-I antigens. J Infect Dis 1999, 179:329-336.

37. Pontesilli O, Kerkhof-Garde S, Notermans DW, Foudraine NA, Roos MT, Klein MR, Danner SA, Lange JM, Miedema F: Functional T cell reconstitution and human immunodeficiency virus-I-specific cell-mediated immunity during highly active antiretroviral therapy. J Infect Dis 1999, 180:76-86.

38. Jansen CA, Piriou E, De Cuyper IM, van Dort K, Lange JM, Miedema $F$, van Baarle $D$ : Long-term highly active antiretroviral therapy in chronic HIV-I infection: evidence for reconstitution of antiviral immunity. Antivir Ther 2006, II:105-1 I6.

39. Sester U, Sester M, Kohler H, Pees HW, Gartner BC, Wain-Hobson S, Bocharov G, Meyerhans A: Maintenance of HIV-specific central and effector memory CD4 and CD8 T cells requires antigen persistence. AIDS Res Hum Retroviruses 2007, 23:549-553.

40. Rosenberg ES, Altfeld M, Poon SH, Phillips MN, Wilkes BM, Eldridge RL, Robbins GK, D'Aquila RT, Goulder PJ, Walker BD: Immune control of HIV-I after early treatment of acute infection. Nature 2000, 407:523-526.

41. Palefsky JM, Minkoff H, Kalish LA, Levine A, Sacks HS, Garcia P, Young $M$, Melnick S, Miotti P, Burk R: Cervicovaginal human papillomavirus infection in human immunodeficiency virus- $\mathrm{I}$ (HIV)positive and high-risk HIV-negative women. J Natl Cancer Inst 1999, $91: 226-236$.

42. Heard I, Schmitz V, Costagliola D, Orth G, Kazatchkine MD: Early regression of cervical lesions in HIV-seropositive women receiving highly active antiretroviral therapy. Aids 1998, 12:1459-1464.

43. Heard I, Tassie JM, Kazatchkine MD, Orth G: Highly active antiretroviral therapy enhances regression of cervical intraepithelial neoplasia in HIV-seropositive women. Aids 2002, 16:1799-1802.

44. Moscicki AB, Shiboski S, Hills NK, Powell KJ, Jay N, Hanson EN, Miller S, Canjura-Clayton KL, Farhat S, Broering JM, Darragh TM: Regression of low-grade squamous intra-epithelial lesions in young women. Lancet 2004, 364:1678-1683.

45. Lillo FB, Ferrari D, Veglia F, Origoni M, Grasso MA, Lodini S, Mastrorilli E, Taccagni G, Lazzarin A, Uberti-Foppa C: Human papillomavirus infection and associated cervical disease in human immunodeficiency virus-infected women: effect of highly active antiretroviral therapy. J Infect Dis 200I, I84:547-55I.

46. Strickler HD, Burk RD, Fazzari M, Anastos K, Minkoff H, Massad LS, Hall C, Bacon M, Levine AM, Watts DH, Silverberg MJ, Xue X, Schelcht NF, Melnick S, Palefsky JM: Natural history and possible reactivation of human papillomavirus in human immunodeficiency virus-positive women. J Natl Cancer Inst 2005, 97:577-586.

47. Xi LF, Demers GW, Koutsky LA, Kiviat NB, Kuypers J, Watts DH, Holmes KK, Galloway DA: Analysis of human papillomavirus type 16 variants indicates establishment of persistent infection. J Infect Dis 1995, 172:747-755.

48. Huang SM, McCance DJ: Down regulation of the interleukin-8 promoter by human papillomavirus type $16 \mathrm{E6}$ and E7 through effects on CREB binding protein/p300 and P/CAF. J Virol 2002, 76:87|0-872I.
49. Bernat A, Avvakumov N, Mymryk JS, Banks L: Interaction between the HPV E7 oncoprotein and the transcriptional coactivator p300. Oncogene 2003, 22:787I-788I.

50. Ronco LV, Karpova AY, Vidal M, Howley PM: Human papillomavirus $16 \mathrm{E} 6$ oncoprotein binds to interferon regulatory factor3 and inhibits its transcriptional activity. Genes Dev 1998, I 2:206 I-2072.

51. Doorbar J: Molecular biology of human papillomavirus infection and cervical cancer. Clin Sci (Lond) 2006, I I 0:525-54I.

52. Mota F, Rayment N, Chong S, Singer A, Chain B: The antigen-presenting environment in normal and human papillomavirus (HPV)-related premalignant cervical epithelium. Clin Exp Immunol 1999, I I 6:33-40.

53. Giannini SL, Al-Saleh W, Piron H, Jacobs N, Doyen J, Boniver J, Delvenne $\mathrm{P}$ : Cytokine expression in squamous intraepithelial lesions of the uterine cervix: implications for the generation of local immunosuppression. Clin Exp Immunol 1998, I 13:183-189.

54. El-Sherif AM, Seth R, Tighe PJ, Jenkins D: Quantitative analysis of IL- 10 and IFN-gamma mRNA levels in normal cervix and human papillomavirus type 16 associated cervical precancer. J Pathol 200I, 195: 179-185.

55. Sykes $P$, Smith N, McCormick $P$, Frizelle FA: High-grade vulval intraepithelial neoplasia (VIN 3): a retrospective analysis of patient characteristics, management, outcome and relationship to squamous cell carcinoma of the vulva 1989-1999. Aust N ZJ Obstet Gynaecol 2002, 42:69-74.

56. Ostor AG: Natural history of cervical intraepithelial neoplasia: a critical review. Int J Gynecol Pathol I993, I2: 186-192.

57. Watson AJ, Smith BB, Whitehead MR, Sykes PH, Frizelle FA: Malignant progression of anal intra-epithelial neoplasia. ANZJ Surg 2006, 76:715-717.

58. Offringa R, de Jong A, Toes RE, Burg SH van der, Melief CJ: Interplay between human papillomaviruses and dendritic cells. Curr Top Microbiol Immunol 2003, 276:2 I5-240.

59. Woo YL, Hende M van den, Sterling JC, Coleman N, Crawford RA, Kwappenberg KM, Stanley MA, Burg SH van der: A prospective study on the natural course of low-grade squamous intraepithelial lesions and the presence of HPVI6 E2-, E6- and E7specific T-cell responses. Int J Cancer 2009, I 26(I): |33-4I.

60. Tsukui T, Hildesheim A, Schiffman MH, Lucci J, Contois D, Lawler P, Rush BB, Lorincz AT, Corrigan A, Burk RD, Qu W, Marschall MA, Mann D, Carrington M, Clerici M, Shearer GM, Carbone Dp, Scott DR, Houghten RA, Berzofsky JA: Interleukin 2 production in vitro by peripheral lymphocytes in response to human papillomavirus-derived peptides: correlation with cervical pathology. Cancer Res 1996, 56:3967-3974.

61. de Vos van Steenwijk PJ, Piersma SJ, Welters MJ, Hulst JM van der, Fleuren G, Hellebrekers BW, Kenter GG, Burg SH van der: Surgery followed by persistence of high-grade squamous intraepithelial lesions is associated with the induction of a dysfunctional HPVI6-specific T-cell response. Clin Cancer Res 2008, | 4:7|88-7| 95.

62. Visser J, van Baarle D, Hoogeboom BN, Reesink N, Klip H, Schuuring E, Nijhuis E, Pawlita M, Bungener L, de Vries-Idema J, Nijman H, Miedema F, Daemen T, Zee A van der: Enhancement of human papilloma virus type 16 E7 specific T cell responses by local invasive procedures in patients with (pre)malignant cervical neoplasia. Int I Cancer 2006, I I 8:2529-2537.

63. van Poelgeest MI, van Seters $M$, van Beurden M, Kwappenberg KM, Heijmans-Antonissen C, Drijfhout JW, Melief C], Kenter GG, Helmerhorst TJ, Offringa R, Burg SH van der: Detection of human papillomavirus (HPV) 16-specific CD4+ T-cell immunity in patients with persistent HPVI6-induced vulvar intraepithelial neoplasia in relation to clinical impact of imiquimod treatment. Clin Cancer Res 2005, I I:5273-5280.

64. Nobbenhuis MA, Helmerhorst TJ, Brule AJ van den, Rozendaal L, Voorhorst FJ, Bezemer PD, Verheijen RH, Meijer CJ: Cytological regression and clearance of high-risk human papillomavirus in women with an abnormal cervical smear. Lancet 200I, 358: $1782-1783$.

65. Schuman P, Ohmit SE, Klein RS, Duerr A, Cu-Uvin S, Jamieson DJ, Anderson J, Shah KV: Longitudinal study of cervical squamous intraepithelial lesions in human immunodeficiency virus (HIV)-seropositive and at-risk HIV-seronegative women. Infect Dis 2003, 188:128-136. 
66. De Vuyst H, Clifford GM, Nascimento MC, Madeleine MM, Franceschi $\mathrm{S}$ : Prevalence and type distribution of human papillomavirus in carcinoma and intraepithelial neoplasia of the vulva, vagina and anus: a meta-analysis. Int J Cancer 2009, I 24: |626-1636.

67. Wilkin TJ, Palmer S, Brudney KF, Chiasson MA, Wright TC: Anal intraepithelial neoplasia in heterosexual and homosexual HIV-positive men with access to antiretroviral therapy. J Infect Dis 2004, 190: I685-169I.

68. Abramowitz L, Benabderrahmane D, Ravaud P, Walker F, Rioux C, Jestin C, Bouvet E, Soule JC, Leport C, Duval X: Anal squamous intraepithelial lesions and condyloma in HIV-infected heterosexual men, homosexual men and women: prevalence and associated factors. Aids 2007, 2 I: | 457-|465.

69. Palefsky JM, Holly EA, Ralston ML, Jay N: Prevalence and risk factors for human papillomavirus infection of the anal canal in human immunodeficiency virus (HIV)-positive and HIV-negative homosexual men. J Infect Dis 1998, I77:36 I-367.

70. Welters MJ, Logt $P$ van der, Eeden SJ van den, Kwappenberg KM, Drijfhout JW, Fleuren G], Kenter GG, Melief C], Burg SH van der, Offringa R: Detection of human papillomavirus type $18 \mathrm{E6}$ and E7-specific CD4+ T-helper I immunity in relation to health versus disease. Int ] Cancer 2006, I I 8:950-956.

7I. Youde SJ, Dunbar PR, Evans EM, Fiander AN, Borysiewicz LK, Cerundolo V, Man S: Use of fluorogenic histocompatibility leukocyte antigen-A*020 I/HPV $16 \mathrm{E7}$ peptide complexes to isolate rare human cytotoxic T-lymphocyte-recognizing endogenous human papillomavirus antigens. Cancer Res 2000, 60:365-371.

72. Burg SH van der, Piersma SJ, de Jong A, Hulst JM van der, Kwappenberg KM, Hende $M$ van den, Welters MJ, Van Rood J], Fleuren G], Melief CJ, Kenter GG, Offringa R: Association of cervical cancer with the presence of CD4+ regulatory $T$ cells specific for human papillomavirus antigens. Proc Natl Acad Sci USA 2007, I 04: | 2087-12092

73. Piersma SJ, Jordanova ES, van Poelgeest MI, Kwappenberg KM, Hulst JM van der, Drijfhout JW, Melief CJ, Kenter GG, Fleuren GJ, Offringa $\mathrm{R}$, Burg $\mathrm{SH}$ van der: High number of intraepithelial CD8+ tumor-infiltrating lymphocytes is associated with the absence of lymph node metastases in patients with large early-stage cervical cancer. Cancer Res 2007, 67:354-36I.

74. Jordanova ES, Gorter A, Ayachi O, Prins F, Durrant LG, Kenter GG, Burg SH van der, Fleuren GJ: Human Leukocyte Antigen Class I, MHC Class I Chain-Related Molecule A, and CD8+/Regulatory T-Cell Ratio: Which Variable Determines Survival of Cervical Cancer Patients? Clin Cancer Res 2008, I 4:2028-2035.

75. Karim R, Jordanova ES, Piersma SJ, Kenter GG, Chen L, Boer JM, Melief C], Burg SH van der: Tumor-expressed B7-HI and B7-DC in relation to $P D-I+T$-cell infiltration and survival of patients with cervical carcinoma. Clin Cancer Res 2009, I 5:634|-6347.

76. Goldie SJ, Kuntz KM, Weinstein MC, Freedberg KA, Palefsky JM: Cost-effectiveness of screening for anal squamous intraepithelial lesions and anal cancer in human immunodeficiency virus-negative homosexual and bisexual men. Am J Med 2000, 108:634-64I.

77. Kreuter A, Brockmeyer NH, Altmeyer P, Wieland U: Anal intraepithelial neoplasia in HIV infection. J Dtsch Dermatol Ges 2008, 6:925-934.

78. Wieland U, Brockmeyer NH, Weissenborn SJ, Hochdorfer B, Stucker M, Swoboda J, Altmeyer P, Pfister H, Kreuter A: Imiquimod treatment of anal intraepithelial neoplasia in HIV-positive men. Arch Dermatol 2006, | 42: |438-| 444.

79. Kreuter A, Potthoff A, Brockmeyer NH, Gambichler T, Stucker M, Altmeyer P, Swoboda J, Pfister H, Wieland U: Imiquimod leads to a decrease of human papillomavirus DNA and to a sustained clearance of anal intraepithelial neoplasia in HIV-infected men. J Invest Dermatol 2008, I 28:2078-2083.

80. Sanclemente G, Herrera S, Tyring SK, Rady PL, Zuleta JJ, Correa LA, He Q, Wolff JC: Human papillomavirus (HPV) viral load and HPV type in the clinical outcome of HIV-positive patients treated with imiquimod for anogenital warts and anal intraepithelial neoplasia. J Eur Acad Dermatol Venereol 2007, 21:1054-1060.

8I. van Seters M, van Beurden M, ten Kate FJ, Beckmann I, Ewing PC, Eijkemans MJ, Kagie MJ, Meijer CJ, Aaronson NK, Kleinjan A, Heijmans-Antonissen C, Zijlstra FJ, Burger MP, Helmerhorst TJ: Treat- ment of vulvar intraepithelial neoplasia with topical imiquimod. N Engl J Med 2008, 358:|465-|473.

82. Franceschi $\mathrm{S}$, De Vuyst $\mathrm{H}$ : Human papillomavirus vaccines and anal carcinoma. Curr Opin HIV AIDS 2009, 4:57-63.

83. Klencke B, Matijevic M, Urban RG, Lathey JL, Hedley ML, Berry M, Thatcher J, Weinberg V, Wilson J, Darragh T, Jay N, Da Costa M, Palefsky JM: Encapsulated plasmid DNA treatment for human papillomavirus I6-associated anal dysplasia: a Phase I study of ZYCI OI. Clin Cancer Res 2002, 8: I028-I037.

84. Palefsky JM, Berry JM, Jay N, Krogstad M, Da Costa M, Darragh TM, Lee JY: A trial of SGN-00IOI (HspE7) to treat high-grade anal intraepithelial neoplasia in HIV-positive individuals. Aids 2006, 20: II5I-II55.

85. Sheets EE, Urban RG, Crum CP, Hedley ML, Politch JA, Gold MA, Muderspach LI, Cole GA, Crowley-Nowick PA: Immunotherapy of human cervical high-grade cervical intraepithelial neoplasia with microparticle-delivered human papillomavirus I6 E7 plasmid DNA. Am J Obstet Gynecol 2003, I 88:9|6-926.

86. Trimble CL, Peng S, Kos F, Gravitt P, Viscidi R, Sugar E, Pardoll D, Wu TC: A phase I trial of a human papillomavirus DNA vaccine for HPVI 6+ cervical intraepithelial neoplasia 2/3. Clin Cancer Res 2009, I 5:36I-367.

87. Kenter GG, Welters MJ, Valentijn AR, Lowik MJ, Berends-van der Meer DM, Vloon AP, Drijfhout JW, Wafelman AR, Oostendorp J, Fleuren GJ, Offringa R, Burg SH Van der, Melief CJM: Phase I immunotherapeutic trial with long peptides spanning the E6 and E7 sequences of high-risk human papillomavirus 16 in endstage cervical cancer patients shows low toxicity and robust immunogenicity. Clin Cancer Res 2008, I4:169-177.

88. Welters MJ, Kenter GG, Piersma SJ, Vloon AP, Lowik MJ, Berends-van der Meer DM, Drijfhout JW, Valentijn AR, Wafelman AR, Oostendorp J, Fleuren GJ, Offringa R, Melief CJM, Burg SH Van der: Induction of tumor-specific CD4+ and CD8+ T-cell immunity in cervical cancer patients by a human papillomavirus type 16 E6 and E7 long peptides vaccine. Clin Cancer Res 2008, 14:178-187.

89. Melief CJ, Burg SH van der: Immunotherapy of established (pre)malignant disease by synthetic long peptide vaccines. Nat Rev Cancer 2008, 8:35I-360.

90. van Seters $M$, van Beurden $M$, de Craen $A$ J: Is the assumed natural history of vulvar intraepithelial neoplasia III based on enough evidence? A systematic review of 3322 published patients. Gynecol Oncol 2005, 97:645-65I.
Publish with Bio Med Central and every scientist can read your work free of charge

"BioMed Central will be the most significant development for disseminating the results of biomedical research in our lifetime. "

Sir Paul Nurse, Cancer Research UK

Your research papers will be:

- available free of charge to the entire biomedical community

- peer reviewed and published immediately upon acceptance

- cited in PubMed and archived on PubMed Central

- yours - you keep the copyright

Submit your manuscript here:

http://www.biomedcentral.com/info/publishing_adv.asp
BioMedcentral 